brazilianpoliticalsciencereview

ARTICLE

\title{
Future electoral impacts of having a female mayor*
}

\author{
Paulo Arvate \\ Fundação Getúlio Vargas, Brazil \\ Sergio Firpo \\ Insper Instituto de Ensino e Pesquisa, Brazil \\ Renan Pieri \\ Insper Instituto de Ensino e Pesquisa, Brazil
}

\begin{abstract}
We explore an electoral quasi-experiment where a woman nearly won or lost to a man in a mayoral election. Our data combines municipal Brazilian election results, which occur every four years, with municipal level votes for female and male candidates in state and federal deputy elections, whose districts are larger than the municipalities. Our results show that when voters are exposed to a female leader, the relative number of votes given to female candidates increases. This result depends on the political environment in which the exposure occurs. These effects on the electorate's response tend to be stronger: 01. in municipalities where there is a previous higher proportion of female councilors, and 02. when the mayors have higher education levels. Our results provide evidence that the observed electorate's gender preferences in politics are alterable, but that policy interventions aimed to equalize access will be more effective if they are targeted at underrepresented populations that have the correct skill requirements to perform in leadership positions.
\end{abstract}

Keywords: Mayor election; electoral behavior; female political participation; electoral quasi-experiment; Brazil.

(*) http://dx.doi.org/10.1590/1981-3821201700020001

For data replication, see www.bpsr.org.br/files/archives/Dataset_Arvate_et al

This work originated from a project that received financial support from the World Bank under the name 'Gender and Agency in Brazil: the Impacts of Female Local Leaders'. We have benefited from the comments of Fernanda Brollo, Joana Monteiro, Elizaveta Perova, Sarah Reynolds, Johanna Karin Rickne, and participants of the workshop on Chronic Poverty and Gender and Agency at the World Bank headquarters, the 35th Brazilian Meeting of Econometrics, and participants of the 2013 Midwest Political Science Association (the title of the work presented at this last conference was 'Discrimination in Politics, Role Model Effects, and Empowerment: What changes when a woman becomes the local political leader?'). 
$\mathrm{T}$ he glass ceiling, or the low number of women at the top positions of most careers, is a concern in many modern societies. Understanding the causes of this imbalance is important in order to design correct interventions that can mitigate against it. Particularly in the political arena, there is a significant lack of women in legislative and executive elected offices (BALTRUNAITE et al., 2014; BEAMAN et al., 2009; DE PAOLA et al., 2010; LAWLESS, 2004). The literature points to the influence of supply factors, such as role models (GILARDI, 2015), of demand factors, such as party recruitment (FOLKE and RICKNE, 2012), and of electoral rules, which could be genderbiased (KROOK and SCHWINDT-BAYER, 2013), as the main reasons for the low representation of women in politics.

In this article, we investigate whether another demand factor could explain the relative lack of women in elected offices. We measure how an exogenous change in the electorate's degree of exposure to successful local female politicians impacts on the relative number of votes given to women in key elected offices. As localities that noticeably vote for female candidates may be intrinsically different in many unobservable ways from those that do not, an endogeneity problem may arise. Credible causal inference for this kind of problem will thus depend on availability of a clean research design. We use a regression discontinuity design (RDD) that allows us to estimate the causal effect of being exposed to a female leader on future votes for female candidates.

Because we are looking at women running for several offices, we isolate the 'gender channel'. More specifically, we center our attention on the intramunicipal ratio between votes given to female and male candidates running for several different political offices and investigate whether the previous election of a local female leader can alter the relative future electoral success of women.

Our results indicate that there is a positive effect of exogenously exposing the electorate to a female mayor on the future success of other women in elections. However, these effects on the electorate's choice only flourish in municipalities that have previously exhibited a favorable environment for women in the political arena and where the electorate is exposed to a high-quality female mayor. A very plausible explanation for the change in relative votes given to female candidates is that the electorate's beliefs regarding the capabilities of women in leadership positions have been updated (ARONSON et al., 1999; BLASCOVICH et al., 2001; CROZET and CLAIRE, 
1998; DAVIS and SILVER, 2003). Other untestable potential explanations are the endorsement of female candidates by female mayors and the differential turnout among certain progressive sectors of the electorate in municipalities whose mayors are women $^{1}$. Our research design allows us, nevertheless, to discard some alternative potential explanations for our results such as the strategic reactions of party elites and the pre-existing preferences towards women in politics.

A clear majority of the literature concentrates on the effects of women already in political offices on the relative chances of women achieving the same specific offices in the future (BALTRUNAITE et al., 2014; BEAMAN et al., 2009; BHAVNANI, 2009; DE PAOLA et al., 2010; FERREIRA and GYOURKO, 2014), namely the positions of either councilor or mayor. One possible reason for investigating the effect on only one specific office and not on a larger number of political offices is related to the specifics of electoral systems, which have already been investigated by previous studies ${ }^{2}$. We utilize the Brazilian electoral system, which combines absolute majority voting for executive offices, including mayoral elections, and party-list proportional representation for legislative offices (i.e., state and federal deputies and councilors). There are two interesting aspects of the Brazilian electoral system that are useful for our analysis. First, the election of mayors and councilors occurs every four years, but two years before those for state and federal-level offices (deputies, senators, governors, and president), thus elections for mayors and deputies do not coincide. Second, the electoral district of the local elections is the municipality, whereas the electoral district of the elections for state and federal deputies is the state. This arrangement allows us to look at the impact that electing a female mayor in year ' $t$ ' has on the votes given within municipal boundaries in the elections of deputies in year ' $t+6$ ', for example.

Mayors occupy an important and heavily contested office in Brazilian politics (MIGUEL, 2003), because since the 1988 Federal Constitution, municipalities have had institutional autonomy for establishing their own policies. We have data on votes by

1 For the first mechanism, one would need data on endorsements at the local level. For the second one, however, there are recent preliminary results using individual turnout data that are not consistent with that explanation.

2 For example, being elected to legislative and executive offices can involve either multiple local districts (i.e., state or federal authorities are elected by a district that is either the state or the nation) or only one local district (i.e., mayors and councilors). We select four democratic countries (Brazil, Italy, the US, and Germany) in Tables A1 and A2, available online at BPSR website as supplementary material, as an illustration. 
municipality and candidate gender for different offices in two different geographical electoral district coverages - the municipality and the state. Overall, there are 5,565 municipalities spread over 27 states. Elections for state and federal deputies are based on an open list proportional system and all votes within the state are counted in the final electoral result. For these elections, we do not investigate whether candidates were elected or not; instead, we measure whether in a municipality that 'randomly' elected a female mayor at time ' $t$ ', female candidates for state and federal deputies obtained at time ' $t+6$ ' relatively more votes when compared to municipalities that elected a male mayor.

In this article, we focus on measuring the electorate's overall acceptance of women in politics. Our dependent variables at the municipal level are the ratios of votes for female over male candidates for different elected offices: federal deputy, state deputy, mayor, and city councilor. The way in which the electoral rules determine which candidate will eventually be elected does not influence our measure, as it is robust to the type of link between the votes within local districts and actual election outcomes. Therefore, we do not investigate the differential development of policies based on the mayor's gender, whether general or focused, to meet the demands of the female electorate (BROLLO and TROIANO, 2016; FERREIRA and GYOURKO, 2014)³.

There is an evident endogeneity problem with any empirical investigation that attempts to link the gender of elected politicians to the future relative success of female candidates. The voters who elected female mayors may have different baseline gender preferences than voters who did not elect female mayors, and results could reflect these preference differences. We circumvent this problem by focusing on close mayoral elections (LEE, 2001), where the two most voted candidates were a man and a woman (BROLLO and TROIANO, 2016; FERREIRA and GYOURKO, 2014). We show that in this $\mathrm{RDD}$, there are no important discontinuities in the municipal characteristics prior to the election, which guarantees the internal validity of the design. In a valid RDD, there is no expected systematic difference in the electorate's gender preferences between treated

\footnotetext{
${ }^{3}$ Nevertheless, and for the sake of completeness, we use the same empirical strategy to examine whether there are relevant differences in either the implementation of public policies or resources to do public policies of other levels of government (i.e., a measure of competence) between women and men. We do not observe any differences in the results. The results can be found online at BPSR website, as supplementary material (Part A). See also Brollo and Troiano (2016) for a systematic analysis of the differences in policies.
} 
(female mayor elected within a narrow margin) and control (male mayor elected within a narrow margin) municipalities.

Nevertheless, differential selection may affect the interpretation of our results. For example, if women face far more difficult restrictions in becoming candidates than men (see the example mentioned in BALTRUNAITE et al., 2014; LAWLESS and FOX, 2012), then it is natural to expect that female candidates will be, on average, better qualified than their male counterparts. Note that this situation does not invalidate the $\mathrm{RDD}$, because it does not mean that municipalities have intrinsically different aspects. However, these differences may compromise the external validity of our quasiexperiment if there is no available model for the differential selection. We provide a proxy solution to this problem by examining how elected male and female mayors differ in their observable characteristics. We show that female mayors have higher levels of education than male mayors. We then replicate our RDD by subgroups of mayoral educational level. We separate out mayoral elections in which the elected candidate has completed at least tertiary education from other mayoral elections as a tentative way of isolating the 'pure' gender effect and strengthening the external validity of the experiment ${ }^{4}$.

An important alternative mechanism that would explain our results is that the parties could be offering candidates by gender and locality (ESTEVE-VOLART and BAGUES, 2012). We address this problem by exploring Brazilian electoral rules and the richness of our data. We have voting data by municipality and candidate relating to elections for federal and state deputies that occurred two and six years after the mayor was elected. As noted by Ames (1992) and many others (e.g. FIRPO et al., 2015), electoral success at the municipal level does not guarantee electoral success at the state level. Therefore, it is unlikely that the parties will strategically alter their gender composition for open-list proportional elections as a response to municipal politics. Explanations based on role models can also be discarded, since elections for deputies are run at the state level, not at the municipal or local level, thus ruling out the explanation of female candidates emerging locally due to being inspired by the female

\footnotetext{
${ }^{4}$ In our RDD, the fact that elected female candidates are different from elected male candidates in terms of formal education means that our 'treatment' (having a female mayor) combines the gender and the education of the mayor. Thus, without any effort to control for educational levels of the mayors, it would be necessary, for our results to be generalizable, that the combination of gender and education in our data be the same in other settings.
} 
mayor example. Finally, pre-existing differences in preferences towards candidates' genders should not be relevant in an RDD setup, which guarantees that across the margin cutoff, left-leaning and right-leaning side municipalities should have, on average, similar characteristics.

Our main results show that having a local female leader has a positive effect on the future success of women in politics in two out of the four elected offices investigated. Having a female leader affects the gender ratio of votes for both the legislative office that is recognized as being the gateway to a political career in Brazil, namely municipal councilor, and one of the most prestigious and highly contested legislative offices, that of federal deputy (MIGUEL, 2003).

Nevertheless, these effects exist only when 01 . there is a large proportion of women politicians (municipalities whose previous percentage of female candidates to the council town is higher than the median of all municipalities in the country where mixed-gender races occurred); and 02. mayors have a higher level of education.

For the subsample of mayors with low educational levels, women running in mayoral races four years after the election of a female mayor have fewer votes, relatively, than men when the previous mayor was a man.

Our results, when put together, lead us to conclude that the success of women in politics can be positively affected when the environment (i.e., high previous exposure to female politicians) and the skills of local leaders (higher education) are combined.

This article is organized as follows: section 02 reviews the related literature and states the main hypothesis we test in this article. Section 03 presents the institutional background, datasets, and empirical strategy. In section 04 , we present and discuss our results. Finally, section 05 highlights our conclusions.

\section{Literature on the lack of female participation}

Following the setup developed by Gilardi (2015), Folke and Rickne (2012), and Krook and Schwindt-Bayer (2013), the reasons for the lack of female participation in politics can be grouped into two main factors: supply factors, which are often associated with decisions made by women; demand factors, which are often associated with decisions made by parties and/or the electorate.

There are two major strands within the literature grouped as 'the supply factor'. The first one emphasizes the self-perception of women as not possessing all the 
qualifications to become a competitive candidate. This belief may be motivated by a lack of time or money (NORRIS and LOVENDUSKI, 1995), and the doubts that women harbor concerning their own 'abilities' and qualifications to run for office (LAWLESS and FOX, 2004, 2010; NORRIS and LOVENDUSKI, 1995). The second approach puts emphasis on the reluctance that women show in participating in the parties' primary processes (KANTHAK and WOON, 2014).

There are also two major positions within the literature grouped as 'the demand factor'. The first one addresses the importance of the party elite when it comes to defining women as candidates. The elites that influence the indication of candidates may exert a selection bias against female candidates (KITTILSON, 2006; KROOK, 2006). The second stance puts emphasis on electoral rules, which can create favorable conditions for the election of women (PAXTON, KUNOVICH and HUGHES, 2007). For example, proportional representation offers political parties more opportunities and flexibility to adopt equality strategies that ensure equal numbers of women to men in the selection for election processes (KITTILSON and SCHWINDT-BAYER, 2010). Other examples are: 01. multi-member districts that may be more favorable electorally to women than single-member districts; 02. closed party lists, as parties can include female candidates who might have difficulty getting elected otherwise; and 03. quotas (BEAMAN et al., 2009; KROOK, 2009; TRIPP and KANG, 2008)5, which can increase both the electoral participation (DE PAOLA, 2014) and the quality of elected (female) politicians (BALTRUNAITE et al., 2014).

Our article lies within the literature linked to the demand side. Our working hypothesis is that exposing the electorate to female politicians in locally important elected offices will slowly change the electorate's perception about the role of women in politics. The more qualified the local female official and the more widespread the presence of women in elected offices are, the stronger this effect should be.

\section{Institutional background, definition of variables, and data}

\section{The Brazilian electoral system}

Brazil is a federalist country with three levels of government, namely, federal, state (27 - one of which is the Federal District), and municipalities $(5,565)$.

\footnotetext{
5 The evidence as to what extent women empower female candidates is ambiguous in India (see, e.g. BHALOTRA et al., 2016)
} 
Unlike Mexico, which underwent a long period of single-party dominance (CLEARY, 2007; HECOCK, 2006), but similar to other Latin American countries, such as Argentina, Uruguay, and Chile that lived under dictatorships, Brazilian municipalities enjoy the status of being federation members (they are not subordinate to the state or the federal government). The 1988 Brazilian Constitution has allowed municipalities to have autonomy on budgetary matters, as the local executive may formulate their own budget proposals (including taxes and expenditure) ${ }^{6}$ and present them to the local legislative branch for approval7. Strong evidence shows that the determination of public policy is concentrated in the hands of mayors (SAMUELS, 1997).

Miguel (2003) defines the relative importance of each elected political office in the Brazilian political system. This ranking classifies councilor as the lowest office in a political career followed by that of mayor. However, the size of a municipality defines the importance of the mayor in the broader political scenario, and mayors representing large municipalities are at the top of their careers in this role. State deputies are, in terms of political relevance, somewhat comparable with mayors of medium sized municipalities, whereas federal deputies are equivalent to mayors of large municipalities, which include state capitals. Senators, state governors, and the president rank above these offices.

Local voters simultaneously choose the mayors and councilors in municipalities for a four-year (fixed) term. Since the 1988 Constitution, mayors have been chosen in a one-round election (majoritarian system) for municipalities with fewer than 200,000 registered voters. Run-off elections may occur in municipalities with over 200,000 registered voters, if no mayoral candidate achieves the most valid votes in the first round ( $50 \%$ plus one).

We only use data on municipalities below the 200,000 voters' threshold. By doing this, we excluded approximately 120 of the largest municipalities from our

6 Per the 'Government Finance Statistics Yearbook', IMF, 2003, tax revenues represent, on average, only $24 \%$ of the total revenue of municipalities. Only in the United Kingdom (with a unitary government system and local governments with less autonomy and few attributes), do current transfers amount to a high share of local government revenues. Municipalities in Latin American neighbors, such as Mexico, Chile, and Colombia, are far less dependent on transfers. Federations with large territories and broad social or economic diversity, such as Brazil (e.g., Russia, Canada, Australia, and the US), also have less transfer-dependent local governments. ${ }^{7}$ Each municipality has its own 'constitution', which is called the Organic Law. 
sample. The reason for this decision is to avoid strategic voting behavior where voters do not necessarily reveal their preferences in the first round (FUJIWARA, 2011).

As a direct mechanism to promote female participation since the constitutional amendment of 1997, there have been quotas for women ${ }^{8}$. Of the total number of candidates resulting from the rules prescribed in this article, each party or coalition must reserve at least $30 \%$ and at most $70 \%$ of its candidates for each sex. However, electorally weak candidates for legislative offices typically fill these quotas 9 .

The constitutional amendment of 1997 also establishes that mayors can be reelected (personal reelection establishes a new term limit rule) ${ }^{10}$. Local legislators are elected through an open-list proportional representation system (voters can order the list of either candidates or parties), and no term limit applies for legislative offices.

Elections occur every two years in Brazil. There are local elections every four years, whereas elections for president, governors, senators, federal deputies, and state deputies also occur every four years, two years after the local elections. For national elections, the electoral district is the state, except for the presidential election, during which time the electoral district is the entire country. State and federal deputies are chosen under the same electoral system that is used for municipal councilors.

The Brazilian institutional setting creates an interesting situation that we are able to use to our advantage: it is possible to observe the effect that a female mayor has on the municipal acceptance of candidates running for other political offices several years after her own election. We focus on the effects that occur six years after the mayoral election because two years is likely too short a time span for the effects on electorate behavior to mature. We have data on the electoral results for the state and federal deputies (candidates and votes) at the municipal level. Thus, we are not investigating whether female candidates for federal or state deputy will increase

\footnotetext{
${ }^{8}$ Article 10, paragraph 13, Law 9504, 1997.

${ }_{9}^{9}$ See Part A, table SA.2, available at BPSR website as supplementary material. For councilor, the proportion of women in all elections in our sample was $32 \%$, however only $13 \%$ of elected councilors were women.

${ }^{10}$ Law 9504/1997 does not permit the personal election of members of the Executive more than two consecutive times.
}

(2017) $11(2) \quad$ - $00001-9 / 28$ 
their chances of being elected at the state level (the district relevant for their election). Instead, we are examining whether female candidates that run for these offices will obtain more votes in a geographically well-defined section of the electoral district, the municipality, which either has a female mayor (treatment group) or a male mayor (control group).

\section{Data}

Tables 1.A and 1.B show the definition of the variables that are used in our empirical investigation. The dependent variables are the logarithm of the ratio between the number of votes given to women and the number of votes given to men in each municipality ' $i$ ' in election year ' $t$ ' for the following offices: Mayors, Councilors, Federal Deputies, and State Deputies. We restrict our attention to the municipal elections in which a mixed-gender race took place, using several measures of the success of women in politics as dependent variables ${ }^{11}$.

Table 1A. Definition of variables

\begin{tabular}{ll}
\hline Variables & Building of variables \\
\hline Water Service & $\begin{array}{l}\text { Percentage of houses with water in the } \\
\text { municipality }\end{array}$ \\
Sewer Service & $\begin{array}{l}\text { Percentage of houses with sewer service in the } \\
\text { municipality }\end{array}$ \\
Population & In thousands \\
Theil & Theil index for each municipality \\
Female Population & $\begin{array}{l}\text { Percentage of women in the total municipal } \\
\text { population }\end{array}$ \\
Percentage of literacy - older than 25 & $\begin{array}{l}\text { Percentage of the population that is older than } \\
25 \text { years of age and is literate (in percentage } \\
\text { points from } 1 \text { to } 100)\end{array}$ \\
years & $\begin{array}{l}\text { Natural logarithm of GDP per capita in } \\
\text { thousands } \\
\text { The percentage of households in the rural area } \\
\text { in decimals (0 to 1) }\end{array}$ \\
\hline
\end{tabular}

Source: IBGE, 2000 Census.

11 In Tables A3-A4, available on line as Supplementary material, we present the descriptive statistics of the dependent variables and covariates that are used in our investigation of the different municipalities. These statistics include all municipalities with a mixed-gender race. 
Table 1B. Definition of variables

\begin{tabular}{|c|c|c|}
\hline Variables & Labels & Building of variables \\
\hline Margin & Margin of victory & $\begin{array}{l}\text { Difference in percentage of votes between } \\
\text { female and male candidates for mayor } \\
\text { considering the first and second places in } \\
\text { the first round of municipal elections with } \\
\text { registered voters up to } 200,000 \text { inhabitants }\end{array}$ \\
\hline $\begin{array}{l}\text { Success of } \\
\text { women in } \\
\text { politics }\end{array}$ & $\begin{array}{l}\text { Log of the ratio between the } \\
\text { number of votes given to women } \\
\text { and the number of votes given to } \\
\text { men in the following elections: } \\
\text { Mayors, Councilors, Federal } \\
\text { Deputies, and State Deputies }\end{array}$ & $\begin{array}{l}\text { The logarithm of the ratio between female } \\
\text { and male votes in a specific election. Given } \\
\text { that the district for state and federal } \\
\text { elections is the state, our municipal variable } \\
\text { in these elections considers the geographic } \\
\text { locations (municipalities) where the state } \\
\text { and federal deputies received votes. There } \\
\text { are municipalities where there is no state } \\
\text { and federal vote for women deputies. To } \\
\text { avoid the omission of a municipality, we add } \\
1 \text { for all municipalities before the } \\
\text { logarithm's calculus. In the case of mayors, if } \\
\text { there is no female mayoral candidate, the } \\
\text { votes for women candidates are considered } \\
\text { to be missing. }\end{array}$ \\
\hline Mayors' term & $\begin{array}{l}\text { Elected for either first or second } \\
\text { term }\end{array}$ & $\begin{array}{l}\text { Dummy variables with values equal to } 1 \text { and } \\
\text { zero otherwise }\end{array}$ \\
\hline $\begin{array}{l}\text { Level of } \\
\text { education of } \\
\text { mayors and } \\
\text { mayoral } \\
\text { candidates }\end{array}$ & $\begin{array}{l}\text { Incomplete primary education; } \\
\text { Completed primary education } \\
\text { but not high school; Completed } \\
\text { high school but not higher } \\
\text { education; Completed higher } \\
\text { education }\end{array}$ & $\begin{array}{l}\text { Dummy variables with values equal to } 1 \text { and } \\
\text { zero otherwise }\end{array}$ \\
\hline Parties & $\begin{array}{l}\text { PT (Workers Party), PSDB (Party } \\
\text { of Brazilian Social Democracy), } \\
\text { PFL (Liberal Front Party), and } \\
\text { PMDB party (Brazilian } \\
\text { Democratic Movement Party) }\end{array}$ & $\begin{array}{l}\text { Dummy variables with values equal to } 1 \text { and } \\
\text { zero otherwise. We included two } \\
\text { ideologically left-wing parties (PSDB and } \\
\text { PT), one centrist party (PMDB), and one } \\
\text { ideologically right-wing party using the } \\
\text { classification of Latin America Parties that } \\
\text { was established by Coopedge (1997) as a } \\
\text { source. }\end{array}$ \\
\hline
\end{tabular}

Sources: Superior Electoral Court (TSE) for the election of 2000, 2004, 2008, and 2012 (mayors and councilors) and 1998, 2002, 2006, and 2010 (state and federal deputies). The TSE's electronic data on Brazilian elections are available from 1994. (www.tse.gov.br).

As potential confounding factors, we follow the literature that shows the preference of female candidates for left-wing parties (STINEDURF, 2011), and use party dummies as covariates. We restrict our attention to the largest parties over the period being analyzed and create dummies for the Workers Party - PT, Brazilian Social Democracy Party - PSDB, Brazilian Democratic Movement Party - PMDB, and Liberal Front Party - PFL. We also include several other covariates such as the observable 
characteristics of politicians (for example, level of education) and municipalities (the GDP per capita, the Theil index, etc.) and municipal characteristics (population, the percentage of women as a share of the total municipal population, etc).

The balancing of these covariates between treated and controls is important for the internal validity of our research design. Because the unit of analysis is the municipality, we include the characteristics of female and male candidates separately in the list of covariates. In an RDD, none of these characteristics should be correlated with the gender of the elected mayor in close races ${ }^{12}$.

The participation of women in the Brazilian political system is very limited, although it has grown somewhat in recent years. In the four elections that are considered in our sample $(2000,2004,2008$, and 2012), women were elected mayor in only approximately $12 \%$ of the municipalities ${ }^{13}$.

\section{Empirical strategy}

Given that municipalities that vote more for women may be essentially different from those that vote for men in unobservable aspects, we use an electoral quasiexperiment. Our empirical strategy is to apply a sharp regression discontinuity approach in the same way as Lee, Moretti, and Butler (2004) and Lee (2008). We explore close mayoral races where the two most voted for candidates were necessarily a woman and a man. In our analysis, close elections are those in which a female candidate won by a very narrow margin of votes.

The definition of narrow margin varies depending on the dependent variable being analyzed. We use the method by Calonico et al. (2014) to select those margins. Unlike an RCT (Randomized Control Trial), in which there is a randomization into treatment and control groups that guarantees internal validity of the estimates, an RDD is a valid approach only as long as the assignment to lying either on the right or on the left sides of the discontinuity is random. This is guaranteed only at 'exactly' the

12 The literature also includes the media and its content at the municipal level as being an important control variable (DITTMAR and CARROLL, 2014). We do not consider the media as part of our covariates because we do not have systematic access to the informational content at the local level for the period analyzed. Content is typically more important than simply the existence of local radio stations and newspapers. However, if the experiment is valid, then the non-observable variables should not be a source of bias for our estimates (IMBENS and LEMIEUX, 2008).

${ }^{13}$ See Part A, Table SA.2, available at BPSR website as supplementary material. 
discontinuity itself. That poses a feasibility problem: at any given point in the support of a continuously distributed random variable, as is the running variable (margin of victory), there is no mass. That is to say, that in any sample, there will never be enough data points to run an RDD using only observations at the discontinuity. Therefore, windows or bandwidths around that point are designed so that one can implement the method with sufficient observations. This introduces the following trade-off: a small bandwidth will produce estimates with very small biases (which is good), but be very imprecise (which is bad), whereas a large bandwidth will produce estimates with potentially large biases (which is bad), but be very precise (which is good). Researchers need to face the trade-off between accuracy (no bias) and precision (small variance). Calonico et al. (2014) propose a method to select an optimal bandwidth that deals with that trade-off. To be precise, their method is a data-driven method that minimizes a feasible version of the mean squared error (MSE) criterion in a local linear regression, using triangular kernels. The bandwidth, which is the parameter calibrating the margin's narrowness is optimally chosen as the one that minimizes MSE. In our tables of results, we present the optimal bandwidth values, which are restricted to be the same for both sides of the discontinuity.

RDDs are known as being internally valid, but as having problems with external validity. In our setup, that means that although one could consider our results as being exclusive to close races, an important feature of mayoral races that involve a female candidate is that there is a very high prevalence of races with small differences in the votes between the first and second places ${ }^{14}$. We are also considering the entire country (with different levels of economic, political, and geographic characteristics) for a period of 12 years (excluding only very large municipalities). These features imply that our design is not very different from what women typically experience in the political arena. Therefore, our RDD results are, in this sense, externally valid.

Our treatment variable $D_{i t}$ is a dummy variable that equals one when a woman defeats a male opponent in municipality ' $\mathrm{i}$ ' in the year ' $\mathrm{t}$ ' in a mayoral race. The control group $\left(D_{i t}=0\right)$ is formed by the municipalities that elected men for mayors. The running variable is the margin of victory $\left(\operatorname{Margin}_{i t}\right)$ that is defined as the difference in the votes between female and male candidates. We only include races where the two most voted

${ }^{14}$ See Part C, Figure SC.1 for more details (at BPSR website as Supplementary material). 
for candidates were necessarily a man and a woman. Thus, the relation between $D_{i t}$ and Margin $_{i t}$ can be written as:

$$
D_{i t}=\left\{\begin{array}{l}
1 \text { if } \text { Margin }_{i t}>0 \\
0 \text { otherwise }
\end{array}\right.
$$

Therefore, the cutoff where the margin of victory equals zero corresponds to a single criterion for determining the candidate's gender. We define the parameter $\beta$ as the impact of exogenously exposing the electorate of municipality 'i' to a local female leader from time ' $\mathrm{t}$ ' to time ' $\mathrm{t}+\tau$ ' on the votes for female candidates relative to the votes for male candidates. The relation between the dependent variable is $Y_{i t+\tau}$ and the parameter $\beta$ is therefore:

$$
\beta=\lim _{\operatorname{Margin} \downarrow 0} E\left(Y_{i t+\tau} \mid \operatorname{Margin}_{i t}\right)-\lim _{\operatorname{Margin} \uparrow 0} E\left(Y_{i t+\tau} \mid \operatorname{Margin}_{i t}\right)
$$

We use the estimator that is suggested by Calonico, Cattaneo, and Titiunik (2014) to estimate $\beta$. Calonico et al. (2014) show that the non-parametric estimation of (2) by local linear regressions typically leads to choices of bandwidths that are too 'large', which means that there will be a large asymptotic bias term. These authors propose a way to correct for the bias, which is the method that we use in this study. Finally, they also suggest a bandwidth selection rule, which we also utilize.

\section{Interpreting the empirical strategy}

The interpretation of the parameter $\beta$ requires some further consideration. What do we mean by the impact of 'having a female mayor'? Are we interested in any potential female mayor or the female mayors that were elected in close races in municipalities and within the period being analyzed? We obviously obtain the latter, but is that the parameter of interest? If elected male and female mayors in our data were similar in their characteristics, then we know that our results would be capturing the pure gender effect of the mayor. However, this is not true in our data.

In Table 02, we can see that political variables are well balanced, meaning that elected male and female mayors have no differential affiliation to parties. Nevertheless, female mayors are clearly better educated than male mayors. 
The evidence that male and female mayors differ in education does not invalidate the RDD, because this fact does not mean that municipalities have intrinsically different aspects (IMBENS and LEMIEUX, 2008) depending on the side of the cutoff point. The difference does not affect the internal validity of the design. However, it confounds our interpretation of the 'pure gender effect' because the results presented mix both the pure effect of gender and those that are caused by the differences in educational level. Disentangling these effects is key to policy implications.

Table 02. Balance tests of characteristics between mayors in treated (female mayor) and control (male mayor) municipalities

\begin{tabular}{lc}
\hline Variable & Coefficients \\
\hline PT party & -0.033 \\
& $(0.032)$ \\
PSDB party & {$[0.147]$} \\
& 0.015 \\
PFL party & {$[0.033)$} \\
& {$[0.186]$} \\
& -0.021 \\
PMDB party & {$[0.033)$} \\
& {$[0.156]$} \\
Mayor with incomplete primary education & -0.005 \\
& $0.036)$ \\
Mayor with completed primary education, & {$[0.211]$} \\
but no high school & -0.059 \\
& {$[0.029)^{* *}$} \\
Mayor with completed high school, & {$[0.177]$} \\
but no higher education & -0.147 \\
Mayor with completed higher education & {$[0.034)^{* * *}$} \\
& {$[0.151]$} \\
& -0.007 \\
& {$[0.044)$} \\
& {$[0.189]$} \\
\hline
\end{tabular}

Note: ${ }^{* * *} \mathrm{p}<0.01,{ }^{* *} \mathrm{p}<0.05,{ }^{*} \mathrm{p}<0.1 .01$. Bias-corrected RD estimates with robust variance estimator using Calonico et al. (2014). We estimate a local polynomial of degree 1 and triangular kernel. Standard errors are between parentheses. Same bandwidths for both sides of the discontinuity are displayed in brackets. 02 . Mixed-gender races defined by mayoral elections in which the two most voted for candidates are a woman and a man. 03. Municipalities with more than 200,000 voters are excluded to avoid the possibility of a second round. 04 . Number of observations is 3,891 .

Education is of course not the only dimension that one could use to measure politician quality. However, there is some recent literature showing the relationship between the educational level of politicians and their overall performance in office, 
which is an ex-post measure of quality. For instance, Galasso and Nannicini (2011) measure the quality of politicians on three ex-ante dimensions (i.e., years of schooling, previous market income, and local government experience), and find that members of the Italian Parliament with higher ex-ante quality levels are more likely to run in contestable districts and their subsequent performance is better. According to Ferreira and Gyourko (2014), women mayors have a higher level of political skills than men, and thus, they have an advantage as incumbents over comparable male candidates.

To analyze the 'pure gender effect', and separate the gender effect from education, we run separate RD designs. We stratify the design in the subsamples of the municipalities and amongst the elected mayors with and without higher levels of education ${ }^{15}$. By running these two parallel quasi-experiments, we only compare mayors with the same level of education. Within each stratum, we obtain cleaner 'pure gender effects' resulting from the election of a female leader.

\section{Validating the empirical strategy}

We run some validity tests to confirm the internal and external consistencies of our RDD (EGGERS et al., 2013; IMBENS and LEMIEUX, 2008). First, we test whether there are differences in densities (McCRARY, 2008) between treated (female mayor) and control (male mayor) municipalities to check for manipulation ${ }^{16}$.

We then use the RDD described above to examine how treated and control municipalities differ in their pre-existing observable characteristics. Since we are interested in isolating a pure gender effect from the one derived from differential educational attainment, we divided the sample into municipalities with elected mayors that either had or did not have a college degree.

Municipal characteristics, such as the percentage of houses with water and sewer services, percentage of literate people who are over 25 years old, population size, per capita income, percentage of women, Theil index, and percentage of rural dwellers are all balanced between treated and control municipalities, as shown in Table 03.

15 To avoid an extensive number of subsamples with reduced observations, we compare higher education with grouped lower educational levels.

${ }^{16}$ A histogram with different bins (02\%, 01\%, and 0.5\%) and density functions for each side of the cutoff is available on the BPSR website as Supplementary material (Part C: Figure SC.1). Both the histogram and the densities show that there is no electoral manipulation (discontinuity) near the margin of victory that is equal to zero. The McCrary test $(-0.0388)$ confirms the visual inspection. 
Table 03. Balance test for municipal characteristics by mayoral educational level

\begin{tabular}{lcc} 
& Do Not Have Higher Education & Have Higher Education \\
\hline Percentage of houses with & 0.019 & 0.017 \\
Water & $0.034)$ & $0.035)$ \\
& {$[0.189]$} & {$[0.189]$} \\
Percentage of houses with & 0.006 & 0.034 \\
sewer service & $0.036)$ & $0.045)$ \\
& {$[0.178]$} & {$[0.178]$} \\
Percentage of literacy- older & -2.296 & 0.846 \\
than 25 & $(2.221)$ & $(2.349)$ \\
& {$[0.148]$} & {$[0.148]$} \\
Population (in thousands) & -1415.948 & 4684.109 \\
& $(1667.842)$ & $(4584.699)$ \\
Log per capita GDP & {$[0.144]$} & {$[0.144]$} \\
& -0.628 & 0.13 \\
Percentage of women & $(0.396)$ & $0.669)$ \\
& {$[0.127]$} & {$[0.127]$} \\
Theil index & -0.003 & -0.002 \\
& $(0.002)$ & $0.002)$ \\
Percentage of rural dwellers & {$[0.138]$} & {$[0.138]$} \\
& -0.003 & 0.014 \\
& $(0.015)$ & $(0.017)$ \\
& {$[0.221]$} & {$[0.221]$} \\
& -0.021 & -0.002 \\
& $(0.032)$ & $0.033)$ \\
& {$[0.172]$} & $0.172]$ \\
\hline
\end{tabular}

Note: ${ }^{* * *} \mathrm{p}<0.01,{ }^{* *} \mathrm{p}<0.05, * \mathrm{p}<0.1$. 01. Bias-corrected RD estimates with robust variance estimator using Calonico et al. (2014). We estimate a local polynomial of degree 1 and triangular kernel. Standard errors are between parentheses. Same bandwidths for both sides of the discontinuity are displayed in brackets. 02. Mixed-gender races defined by mayoral elections in which the two most voted for candidates are a woman and a man. 03. Municipalities with more than 200,000 electors are excluded. 04. Number of observations is 1,601 for municipalities whose mayor does not have higher education and 1,498 observations in the other case.

Table 04. Balance test for lagged dependent variables by educational level

\begin{tabular}{lcc} 
& Do Not Have Higher Education & Have Higher Education \\
\hline Log of W/M vote share for & -0.101 & 0.042 \\
federal deputies - 6 years & $(0.322)$ & $0.303)$ \\
Before & {$[0.17]$} & $0.183]$ \\
Log of W/M vote share for & 0.238 & -0.224 \\
state deputies - 6 years before & $(0.264)$ & $0.263)$ \\
& {$[0.184]$} & {$[0.179]$} \\
Log of W/M vote share for & -0.048 & 0.311 \\
mayors - 4 years before & $(0.263)$ & $0.389)$ \\
& {$[0.125]$} & $0.137]$ \\
Log of W/M vote share for & 0.025 & -0.064 \\
councilors - 4 years before & $(0.113)$ & $0.129]$ \\
& {$[0.149]$} & {$[0.211]$}
\end{tabular}

Note: ${ }^{* * *} \mathrm{p}<0.01,{ }^{* *} \mathrm{p}<0.05, * \mathrm{p}<0.1 .01$. Bias-corrected RD estimates with robust variance estimator using Calonico et al. (2014). We estimate a local polynomial of degree 1 and triangular kernel. Standard errors are between parentheses. Same bandwidths for both sides of the discontinuity are displayed in brackets. 02. Mixed-gender races are defined by mayoral elections in which the two most voted for candidates are a woman and a man. 03. Municipalities with more than 200,000 voters are excluded. 04. Number of observations is 1,690 for municipalities whose mayor does not have higher education and 1,577 for municipalities with mayors with higher education. 
Using the RDD described above, we then ran balancing tests on the municipal lagged variables for the same stratified (on mayoral education) samples. Table 04 shows that the balancing tests for the lagged variables are non-significant for all the dependent variables. Finally, we also compared the individual characteristics of same-gender candidates (women/winners compared with women/losers and men/losers compared with men/winners) ${ }^{17}$.

\section{Results}

Table 05 shows the stratified results of having a local female leader on several measures of the future electoral success of women for different political offices (e.g., federal deputy, state deputy, councilor, and mayor) by educational level (elected mayors from mixed-gender races who either 'do not have higher education' or 'have higher education').

We present the general results of mixed-gender races (all) and the results for different subsamples. Our subsamples are the following: 01. municipalities with elected mayors in their first term; 02. municipalities with elected mayors in their second term; and 03. elections where the elected mayor is not running. The subsample described in 03 attempts to avoid the mayors' ability to capture votes for themselves in the election that is being analyzed. In every situation, we considered the municipalities with any number of candidates running for office, but restricted our analysis to those cases where the two most voted for candidates were a woman and $\operatorname{man}^{18}$.

We would expect the coefficients to be positive (i.e., such as in BEAMAN et al., 2009; BHAVNANI, 2009) with other variables if the election of a female leader increases the electoral chances of women. We find, however, that in mayoral elections when we restrict the sample for mayors with low levels of formal education we obtain a negative effect on the relative votes that are given to women compared with men. This effect is concentrated in the next election (four years later) for first-term mayors. In addition, we observe the same effect when the mayor is not running for reelection. For all other offices in any stratification, the results do not change the electoral success of women. Therefore, we noted that, in principle, there was no systematic change in the success of women in politics as a result of exposure to a local female leader.

17 The results are available at the BPSR website as Supplementary material, Table A5.

18 We did a robustness check for the races with only two candidates as in Brollo and Troiano (2016). The results are similar and can be requested from the authors. 
Table 05. Success of women in politics - stratified results by educational level

\begin{tabular}{|c|c|c|c|c|c|c|c|c|}
\hline & All & First Term & $\begin{array}{l}\text { Second } \\
\text { Term }\end{array}$ & \multirow{2}{*}{$\begin{array}{l}\text { Mayor is } \\
\text { not } \\
\text { running } \\
\text { on }\end{array}$} & All & $\begin{array}{l}\text { First } \\
\text { Term }\end{array}$ & $\begin{array}{l}\text { Second } \\
\text { Term }\end{array}$ & \multirow[t]{2}{*}{$\begin{array}{l}\text { Mayor is } \\
\text { not } \\
\text { running }\end{array}$} \\
\hline & \multicolumn{3}{|c|}{ Do Not Have Higher Education } & & \multicolumn{3}{|c|}{ Have Higher Education } & \\
\hline Log of W/M vote Share & 0.103 & 0.547 & -1.019 & 0.124 & 0.704 & 0.389 & 0.89 & 0.457 \\
\hline for federal deputies - 6 & $(0.394)$ & $(0.438)$ & $(0.726)$ & $(0.402)$ & $(0.391)^{*}$ & $(0.468)$ & $(0.763)$ & $(0.359)$ \\
\hline years later & [0.119] & [0.155] & {$[0.118]$} & {$[0.116]$} & {$[0.167]$} & [0.139] & {$[0.221]$} & {$[0.204]$} \\
\hline Log of W/M vote share & 0.223 & 0.686 & -0.87 & 0.274 & 0.015 & -0.056 & -0.018 & 0.053 \\
\hline for state deputies - 6 & $(0.338)$ & $(0.467)$ & $(0.54)$ & $(0.351)$ & $(0.407)$ & $(0.636)$ & $(0.811)$ & $(0.442)$ \\
\hline years later & [0.139] & [0.117] & {$[0.124]$} & {$[0.13]$} & {$[0.176]$} & [0.152] & {$[0.136]$} & {$[0.157]$} \\
\hline Log of $\mathrm{W} / \mathrm{M}$ vote & -0.411 & -0.977 & 0.128 & -0.869 & -0.248 & 0.025 & -0.499 & -0.445 \\
\hline share for mayors - 4 & $(0.251)$ & $(0.354)^{* * *}$ & $(0.481)$ & $(0.45)^{*}$ & $(0.241)$ & $(0.344)$ & $(0.514)$ & $(0.751)$ \\
\hline years later & [0.148] & {$[0.088]$} & {$[0.167]$} & {$[0.176]$} & {$[0.12]$} & [0.121] & {$[0.133]$} & {$[0.167]$} \\
\hline Log of $\mathrm{W} / \mathrm{M}$ vote & 0.144 & 0.316 & 0 & 0.132 & 0.168 & 0.187 & 0.201 & 0.162 \\
\hline share for councilors - & $(0.115)$ & $(0.182)^{*}$ & $(0.16)$ & $(0.117)$ & $(0.127)$ & $(0.182)$ & $(0.176)$ & $(0.129)$ \\
\hline 4 years later & {$[0.181]$} & {$[0.13]$} & {$[0.184]$} & {$[0.181]$} & {$[0.195]$} & {$[0.233]$} & {$[0.161]$} & {$[0.2]$} \\
\hline
\end{tabular}

Note: ${ }^{* * *} \mathrm{p}<0.01,{ }^{* *} \mathrm{p}<0.05,{ }^{*} \mathrm{p}<0.1$. 01. Bias-corrected RD estimates with robust variance estimator using Calonico et al. (2014). We estimate a local polynomial of degree 1 and triangular kernel. Standard errors are between parentheses. Same bandwidths for both sides of the discontinuity are displayed in brackets. 02 . Mixed-gender races are defined by mayoral elections where the two most voted for candidates are a woman and a man. 03. Municipalities with more than 200,000 voters are excluded. 04. 'All': all sample; 'First term': municipalities with mayors in their first mandate; 'Second term': municipalities with mayors in their second mandate; 'Mayor is not running': regressions that exclude mayors who are elected in the baseline year (Year $t$ ). 05. Number of observations is 1,690 for municipalities whose mayor does not have higher education and 1,577 for municipalities with mayors with higher education.

Our first results contrast with Beaman et al. (2012) and Bhavnani (2009), who catalogued well-documented evidence that the election of a woman to a legislative office in India has positive effects on the success of other women in future elections for the same office. Our findings indicate that for the same elected office - mayor - there is a negative impact of being exposed to a female mayor when the mayors do not have higher education. A possible explanation for these findings is that to obtain electoral results, women still need to signal to voters that they are of higher quality, independent of the qualifications of the actual male opponent.

It is important to note in Table 05 that for the overall sample of highly educated mayors, three out of four coefficients (column 'All') are positive, one being statistically significant at p-value smaller than the 0.10 level. Given our hypothesis that longer exposure to elected female officials would affect the electorate's choice, we further investigate this subsample and check whether there are heterogeneous effects that are masked by an average effect. We then consider whether the effects would be more pronounced in environments that are more favorable to women. 


\section{Favorable political environment affects the electoral success of women}

Recent experiences in India and Lesotho show that changes in the electorate's preferences regarding candidates' gender may only occur after the electorate has been massively exposed to female politicians. In 1992, India defined a reserved quota for women in Pradhan positions: one-third of these seats are reserved for women. Following the same policy, in 2005, Lesotho established that $30 \%$ of all single-member Electoral Divisions are reserved for women. The electoral experiment in India has been more explored in the development economics literature. For that country, Beaman et al. (2009) show that the reserved seats for female candidates increased the number of elected women for the same council two elections afterwards, whereas Bhavnani (2009) found that it increased by up to five times the probability that a woman would win elections in comparison with the situation before the policy.

Even though an electoral quota of $30 \%$ exists for female candidates in Brazil, half of the municipalities do not have more than $11 \%$ of women on their councils ${ }^{19}$. Even if we restrict the sample to the municipalities with mixed-gender races for mayor, this proportion remains unaltered.

This low number of women councilors raises doubts regarding whether the election of a female mayor would be enough to change the electorate's choice. We then check whether the future success of women in politics would not be more easily altered by a female leader in communities with larger degrees or intensities of exposure to female politicians. Just electing the mayor may be insufficient for voters to alter their opinions regarding female politicians. To investigate this hypothesis, we ran an additional RDD with a subsample that contains the municipalities whose shares of female candidates running for council is above the national median in the previous local election (not the one used in the RDD). This method attempts to analyze situations where there is greater exposure to female politicians. Several municipalities do not even have a single female candidate elected as councilor. In these cases, if a woman wins the mayoral election by chance, this factor may be insufficient in creating the necessary exposure to female leaders to change the electorate's behavior ${ }^{20}$.

19 The quota is on the proportion of candidates, not on the seats, and this explains the policy's ineffectiveness.

${ }^{20}$ In the Supplementary material, available at BPSR website, Table A6, we present summary statistics of the sample used in this subsection. 
Table 06 presents the results of the stratified samples by mayoral educational level, but they are now restricted to the municipalities whose earlier proportion of female candidates for councilor is above the national median ${ }^{21}$.

Table 06. Success of women in politics by educational level where women candidates are above the national median

\begin{tabular}{|c|c|c|c|c|}
\hline & All & First Term & Second Term & Mayor is not running \\
\hline & \multicolumn{4}{|c|}{ Do Not Have Higher Education } \\
\hline Log of W/M vote share & 0.321 & 1.02 & -1.335 & 0.365 \\
\hline for federal deputies - 6 & $(0.773)$ & $(0.892)$ & $(1.215)$ & $(0.78)$ \\
\hline years later & [0.113] & [0.119] & {$[0.117]$} & [0.115] \\
\hline Log of W/M vote share & -0.34 & -0.125 & -0.893 & -0.32 \\
\hline for state deputies - 6 & $(0.563)$ & $(0.839)$ & $(0.989)$ & $(0.569)$ \\
\hline years later & [0.117] & {$[0.122]$} & [0.118] & [0.119] \\
\hline Log of $\mathrm{W} / \mathrm{M}$ vote & -1.14 & -1.365 & -1.466 & -0.965 \\
\hline share for mayors - 4 & $(0.43)^{* * *}$ & $(0.561)^{* * *}$ & $(0.552)^{* * *}$ & $(0.59)$ \\
\hline years later & {$[0.101]$} & {$[0.078]$} & {$[0.078]$} & {$[0.155]$} \\
\hline Log of $\mathrm{W} / \mathrm{M}$ vote & 0.003 & -0.15 & 0.146 & -0.014 \\
\hline share for councilors & $(0.151)$ & $(0.195)$ & $(0.251)$ & $(0.15)$ \\
\hline \multirow[t]{2}{*}{ - 4 years later } & [0.139] & {$[0.112]$} & {$[0.134]$} & [0.139] \\
\hline & \multicolumn{4}{|c|}{ Have Higher Education } \\
\hline Log of W/M vote share & 2.588 & 2.325 & 4.379 & 2.429 \\
\hline for federal deputies - 6 & $(0.696)^{* * *}$ & $(0.722)^{* * *}$ & $(1.993)^{* * *}$ & $(0.684)^{* * *}$ \\
\hline years later & {$[0.106]$} & {$[0.093]$} & {$[0.119]$} & {$[0.109]$} \\
\hline Log of W/M vote share & 0.782 & 0.417 & 1.668 & 0.692 \\
\hline for state deputies - 6 & $(0.668)$ & $(1.039)$ & $(1.159)$ & $(0.606)$ \\
\hline years later & {$[0.134]$} & {$[0.126]$} & {$[0.101]$} & {$[0.176]$} \\
\hline Log of $\mathrm{W} / \mathrm{M}$ vote & -0.306 & -0.051 & -1.28 & -1.224 \\
\hline share for mayors - 4 & $(0.546)$ & $(0.551)$ & $(0.744)^{*}$ & $(1.149)$ \\
\hline years later & {$[0.158]$} & {$[0.114]$} & {$[0.127]$} & {$[0.148]$} \\
\hline Log of $\mathrm{W} / \mathrm{M}$ vote & 0.407 & 0.256 & 0.365 & 0.437 \\
\hline share for councilors & $(0.206)^{* *}$ & $(0.259)$ & $(0.495)$ & $(0.214)^{* *}$ \\
\hline - 4 years later & {$[0.16]$} & {$[0.137]$} & [0.189] & {$[0.156]$} \\
\hline
\end{tabular}

Note: $* * * \mathrm{p}<0.01, * * \mathrm{p}<0.05, * \mathrm{p}<0.1)$ Bias-corrected RD estimates with robust variance estimator using Calonico et al. (2014). We estimate a local polynomial of degree 1 and triangular kernel. Standard errors are between parentheses. Same bandwidths for both sides of the discontinuity are displayed in brackets. 02. Mixed-gender races are defined by mayoral elections where the two most voted for candidates are a woman and a man. 03. Municipalities with more than 200,000 voters are excluded. 04. The number of women elected to the council corresponds to the last election. 05. 'All': all sample; 'First term': municipalities with mayors in first mandate; 'Second term': municipalities with mayors in second mandate; 'Mayor is not running': regressions that exclude mayors elected in the baseline year (Year t). 06. $\mathrm{N}=662$ for municipalities whose mayor does not have higher education and 664 for municipalities whose mayors have higher education.

The results show a significant change in outcomes when compared to the previous one, mostly in municipalities that have a mayor who has a higher level of education. We observe an increase in the relative votes of women for two political offices when the mayors have higher levels of education (see bottom panel of Table 06,

${ }^{21}$ In the Supplementary material, available at BPSR website, part B, we show all necessary tests to validate the RDD with municipalities where the number of candidates for councilor is above/below the national median. For completeness, we also show these results for municipalities below the national median. 
column 'All'): federal deputies and councilors. The results for state deputies are all positive, but are statistically insignificant. As already stated, two of these offices are very important in the Brazilian political system. The council town has been described several times as the gateway to a political career and the federal deputy office is one of the most prestigious and strongly contested legislative posts.

Intense female exposure is not a guarantee that the electoral success of women will increase after a female mayor is elected. When we restrict our sample to mayors with lower levels of formal education (top panel of Table 06), we get even stronger negative impacts on mayoral elections than those reported in Table 05. We get no effect of a female mayor on the votes for female candidates running for other political offices when the mayor does not have a college degree.

\section{Summary of results}

We looked at the impact of electing a female mayor on the relative votes for female candidates four and six years after she assumed office. Given that female mayors are different from male mayors in relation to their educational attainment, we broke down the analysis into two subsamples: mayors with and without tertiary education. We showed that the only robust result was a decrease in the success of women in politics (negative coefficient) for mayoral elections for the sub-sample of less educated mayors.

We then further investigated the 'one swallow doesn't make a summer' hypothesis and broke down the subsamples for the case in which, for the election prior to the one that brought a woman to the mayoral office, there was a relatively high presence of women on the town council. We showed that high exposure to female politicians is a necessary condition for the election of a female mayor in order to produce effects on the electorate's behavior. Within this environment and for the case when mayors have higher levels of education, we produce robust evidence (Table 06, bottom panel) that being exposed to female mayors does increase the electoral success of women in politics.

Therefore, the success of women in politics can be positively affected when the environment (i.e., high previous exposure to female politicians) and the skills of local leaders (higher education) appear together. The existing literature has emphasized the importance of a favorable environment for women in politics (BEAMAN et al., 2012) and the skill requirements for female candidates (BALTRUNAITE et al., 2014). However, the 
literature had not yet highlighted the importance of combining these two components. Our results provide evidence that these two isolated channels are not as effective in increasing the electoral success of women in politics, compared to when they operate simultaneously.

\section{Conclusions}

This paper investigates how the election of a female mayor can increase the relative number of votes given to other women in future elections. We perform our investigation with local governments in Brazil using a quasi-experiment that allows us to avoid bias selection. Our design of the electoral quasi-experiment follows the recent advancements in the literature on RDD (CALONICO et al., 2014). In our RDD, the treatment used is having a female mayor who was elected in a close election run against a male candidate (i.e., the margin of victory was close to zero). Under these conditions, the electoral outcome and, by consequence, the gender of the elected mayor can be considered 'exogenous'. We explore the electoral quasi-experiment in order to observe changes in the electorate's behavior. Because female mayors are in general better educated than their male mayor counterparts are, we run two parallel quasiexperiments: one for those mayors with a higher level of education and another for those without a higher educational degree. We proceed in this way in order to be able to obtain 'pure gender' effects, netted out from differences in the educational attainment of female and male mayors.

Our strategy for measuring gender-biased voting changes ignited by the election of a female mayor is to examine future voting outcomes at the municipality level. We construct variables that represent the relative local voting success of women compared with men. All results are presented considering the institutional rules, namely, all elections, first and second mayoral terms, and when the previously elected mayor does not run for the elected office under analysis. In the first set of results, we observe that, overall, there is no effect of having a female mayor on the relative local electoral success of women. The only exception is the decrease in relative votes for women in future mayoral elections for the subsample of low educated mayors.

Because the isolated election of a female leader is not enough to trigger future changes in voting patterns for women, as documented by some of the literature, we also investigate whether the null result was an averaging of results coming from different 
environments. We therefore check whether results depend on the degree of previous exposure to female politicians. We separately consider municipalities that assigned larger and smaller than the national median number of seats to female candidates in previous elections to the town council. Our most important and robust results are exactly for municipalities where the percentage of female councilor candidates was higher than the median and with more qualified elected mayors. Under this scenario, there is an important increase in votes for women, when running for councilor and federal deputy four and six years after a woman is 'randomly' elected mayor.

Our results contribute to the literature on differences in electoral performance by gender (BEAMAN et al., 2009; BHAVNANI, 2009; DOLAN, 2010; FERREIRA and GYOURKO, 2014; SANBONMATSU, 2002) by providing results with high internal and external validities. In terms of internal validity, municipalities - the units of analysis below and above the cutoff values in our RDD are well balanced. Regarding external validity, there are two points to be emphasized. First, when a female candidate runs for mayor, close races are the rule, not the exception. Therefore, the potential argument that a close race would not be representative of what most female politicians face when running for office would not be valid. Second, we run two parallel RDDs by educational level because female mayors typically have higher educational levels than male mayors. Thus, policy implications regarding the gender effect of the local leader can be observed even for other environments in which an elected female mayor does not necessarily have more years of education than her male counterpart.

This finding has significant policy implications. Consider, for example, an affirmative action policy designed to increase the electoral success of women via quotas for female leaders. The chances that this type of policy would produce long lasting results on the electorate's perception of women as capable politicians would crucially depend on the provision of the correct circumstances, such as skill requirements and an increased and extended exposure to women in these roles. We believe that our results regarding qualifications and exposure can help formulate policies that are targeted towards equalizing the opportunities between men and women, not only in the political arena but also in other settings where the glass ceiling is an important concern.

Nevertheless, given the limitation of our data, we cannot offer a comprehensive analysis of the precise mechanism behind our results. In fact, several different mechanisms would rationalize our results beyond the channel we emphasize, which is 
that there is a change in the electorate's gender stereotypes. Potential alternative explanations are the endorsement of female candidates by female mayors, the differential turnout among certain progressive sectors of the electorate in municipalities whose mayors are women, strategic reactions of party elites and the pre-existing increases in preferences towards women in politics. We leave for a future research agenda a deeper understanding of the important alternative mechanisms that may have driven our results.

Revised by Priscilla Kreitlon Submitted on July 01,2016 Accepted on May 13, 2017

\section{References}

AMES, Barry (1992), Disparately seeking politicians: strategics and outcomes in Brazilian legislative elections. Paper presented at the Conference of the Latin American Studies Association in Los Angeles.

ARONSON, Joshua; LUSTINA, Michael J; GOOD, Catherine; KEOUGH, Kelli; STEELE, Cloude M., and BROWN, Joseph (1999), When white man can't do math: necessary and sufficient factors in stereotype threat. Journal of Experimental Social Psychology. Vol. 35, № 01, pp. 29-46.

BALTRUNAITE, Audinga; BELLO, Piera; CASARICO, Alessandra, and PROFETA, Paola (2014), Gender quotas and quality of politicias. Journal of Public Economics. Vol. 118, pp. 62-74.

BEAMAN, Lori; DUFLO, Esther; PANDE, Rohini, and TOPALOVA, Petia (2012), Female leadership raises aspirations and educational attainment for girls: a policy experiment in India. Science. Vol. 03, № 335 (6068), pp. 582-586.

BEAMAN, Lori; CHATTOPADHYAY, Raghabendra; DUFLO, Esther; PANDE, Rohini, and TOPALOVA, Petia (2009), Powerful women: does exposure reduce bias? Quarterly Journal of Economics. Vol. 124, № 04, pp. 1497-1540.

BHALOTRA, Sonia; CLOTS-FIGUERAS, Irma and IYER, Lakshmi (2016), Path-breakers: how does women's political participation respond to electoral success? The Economic Journal, forthcoming.

BHAVNANI, Rikhil R. (2009), Do electoral quotas work after they are withdrawn? Evidence from a natural experiment in India. American Journal of Political Science. Vol. 103, № 01, pp. 23-35.

BLASCOVICH, Jim; SPENCER, Steven J.; QUINN, Diane, and STEELE, Cloude M. (2001), African americans and high blood pressure: the role of stereotype threat. Psychological Science. Vol. 12, № 03, pp. 225-229. 
BROLLO, Fernanda and TROIANO, Ugo (2016), What happens when a woman wins an election? Evidence from close races in Brazil. Journal of Development Economics. Vol. 122 , issue C, pp. 28-45.

CALONICO, Sebastian; CATTANEO, Matias D., and TITIUNIK, Rocio (2014), Robust nonparametric confidence intervals for regression-discontinuity designs. Econometrica. Vol. 82, № 06, pp. 2295-2326.

CLEARY, Matthew R. (2007), Electoral competition, participation, and government responsiveness in Mexico. American Journal of Political Science. Vol. 51, № 02, pp. 283-299.

CROZET, Jean Claude and CLAIRE, Theresa (1998), Extending the concept of stereotype threat to social class: the intellectual underperformance of students form low socioeconomic backgrounds. Personality and Social Psychology Bulletin. Vol. 24, № 06, pp. 588-594.

DAVIS, Darren W. and SILVER, Brian D. (2003), Stereotype threat and race of interviewer effects in a survey on political knowledge. American Journal of Political Science. Vol. 47, № 01 , pp. 33-45.

DE PAOLA, Maria and SCOPPA, Vincenzo (2012), The causal impact of closeness on electoral participation exploiting the Italian Dual Ballot System. Working Paper, University of Calabria, № 03.

DE PAOLA, Maria; SCOPPA, Vincenzo, and LOMBARDO, Rosetta (2010), Can gender quotas break down negative stereotypes? Evidence from changes in electoral rules. Journal of Public Economics. Vol. 94, № 05-06, pp. 344-353.

DITTMAR, Kelly and CARROLL, Susan J. (2014), Cracking the 'highest, hardest glass ceiling': women as presidential and vice presidential contenders. In: Gender and elections: shaping the future of American Politics. Edited by CARROLL, Susan J. and FOX, Richard L.. Cambridge: Cambridge University Press. pp. 49-79.

DOLAN, Kathleen (2010), The impact of gender stereotyped evaluations on support for women candidates. Political Behavior. Vol. 32, № 01, pp. 69-88.

EGGERS, Andrew C.; FOLKE, Olle; FOWLER, Anthony; HAINMUELLER, Jens; HALL, Andrew B., and SNYDER Jr., James M. (2013), On the validity of the regression discontinuity design for estimating electoral effects: new evidence from over 40,000 close races. Working Paper.

ESTEVE-VOLART, Berta and BAGUES, Manuel F. (2012), Are women paws in the political game? Evidence from elections to the Spanish senate. Journal of Public Economics. Vol. 96, № 03, pp. 387-399. 
FERREIRA, Fernando and GYOURKO, Joseph (2014), Does gender matter for politicallLeadership? The case of U.S. Mayors. Journal of Public Economics. Vol. 112, issue C, pp. 24-39.

FIRPO, Sergio; PONCZEK, Vladimir, and SANFELICE, Viviane (2015), The relationship between federal budget amendment and local electoral performance. Journal of Development Economics. Vol. 116, pp. 186-198.

FOLKE, Olle and RICKNE, Johanna (2012), Female representation but male rule? Party competition and the political glass ceiling. IFN Working Paper, № 923. Research Institute of Industrial Economics.

FUJIWARA, Thomas (2011), A regression discontinuity test of strategic voting and Duverger's Law. Quarterly Journal of Political Science. Vol. 06, № 03-04, pp. 197-233.

GALASSO, Vincenzo and NANNICINI, Tomaso (2011), Competing on good politicians. American Political Science Review. Vol. 105, № 01, pp. 79-99.

GILARDI, Fabrizio (2015), The temporary importance of role models for women's political representation. American Journal of Political Science. Vol. 59, № 04, pp. 957-970.

HECOCK, R. Douglas (2006), Electoral competition, globalization, and subnational education spending in Mexico, 1999-2004. American Journal of Political Science. Vol. 50, № 04, pp. 950-961.

IMBENS, Guido W. and LEMIEUX, Thomas (2008), Regression discontinuity designs: guide to practice. Journal of Econometrics. Vol. 142, № 02, pp. 615-635.

KANTHAK, Kristin and WOON, Jonathan (2014), Women don't run? Election aversion and candidate entry. American Journal of Political Science. Vol. 59, № 03, pp. 595-612.

KITTILSON, Miki Caul (2006), Challenging parties, changing parliaments: women and elected office in contemporary Western Europe. Columbus: Ohio State University. 191 pp..

KITTILSON, Miki Caul and SCHWINDT-BAYER, Leslie (2010), Engaging citizens: the role of power-sharing institutions. Journal of Politics. Vol. 72, № 04, pp. 990-1002.

KROOK, Mona Lena (2006), Reforming representation: the diffusion of candidate gender quotas worldwide. Politics and Gender. Vol. 02, № 03, pp. 303-327.

KROOK, Mona Lena (2009), Quotas for women in politics: gender and candidate selection reform worldwide. New York: Oxford University Press. 304 pp..

KROOK, Mona Lena and SCHWINDT-BAYER, Leslie (2013), Electoral institutions. In: The Oxford handbook of gender and politics. Edited by WAYLEN, Georgina; CELIS, Karen; KANTOLA, Johanna and WELDON, S. Laurel. Oxford: Oxford University Press. pp. 554578. 
LAWLESS, Jennifer L. (2004), Women, war, and winning elections: gender stereotyping in the post-September 11th Era. Political Research Quarterly. Vol. 57, № 03, pp. 479-490.

LAWLESS, Jennifer L. and FOX, Richard L. (2012), Men rule: the continued underrepresentation in the US Politics. Whashington: Women and Politics Institute. 32 pp..

LAWLESS, Jennifer L. and FOX, Richard L. (2010), It Still Takes A Candidate: Why Women Don't Run for Office. Revised Edition. Cambridge University Press. 256 pp..

LEE, David S. (2008), Randomized experiments from non-random selection in U.S. House elections. Journal of Econometrics. Vol. 142, №02, pp. 675-697.

LEE, David S. (2001), The electoral advantage to incumbency and voters' valuation of politicians' experience: a regression discontinuity analysis of elections to the U.S. National Bureau of Economic Research. Working Paper № 8441.

LEE, David S.; MORETTI, Enrico, and BUTLER, Matthew J. (2004), Do voters affect or elect policies? Evidence from the U.S. House. Quarterly Journal of Economics. Vol. 119, № 03, pp. 807-859.

McCRARY, Justin (2008), Manipulation of the running variable in the regression discontinuity design: a density test. Journal of Econometrics. Vol. 142, № 02, pp. 698714.

MIGUEL, Luís Felipe (2003), Capital político e carreira eleitoral: algumas variáveis na eleição para o Congresso brasileiro. Revista de Sociologia Politica. № 20, pp. 115-134.

NORRIS, Pippa and LOVENDUSKI, Joni (1995), Political recruitment: gender, race, and class in the British parliament. Cambridge: Cambridge University Press. 320 pp..

PAXTON, Pamela; KUNOVICH, Sheri, and HUGHES, Melanie M. (2007), Gender in politics. Annual Review of Sociology. Vol. 33, pp. 263-284.

SAMUELS, David (1997), Determinantes do voto partidário em sistemas eleitorais centrados no candidato: evidências sobre o Brasil. Dados. Vol. 40, № 03.

SANBONMATSU, Kira (2002), Gender stereotypes and vote choice. American Journal of Political Science. Vol. 46, № 01, pp. 20-34.

STINEDURF, Samantha (2011) Gender Stereotypes in the American Electoral Process. Phd Dissertation. Bemidji State University.

TRIPP, Aili Mali and KANG, Alice (2008), The global impact of quotas: on the fast track to increase female legislative representation. Comparative Political Studies. Vol. 41, № 03, pp. 338-361. 


\title{
brazilianpoliticalsciencereview
}

\section{E R R A T U M}

The Editor-in-Chief of the Brazilian Political Science Review manifests that the institutional affiliation of Sergio Firpo and Renan Pieri, authors of the article entitled Future electoral impacts of having a female mayor, DOI: 10.1590/19813821201700020001, published in the Brazilian Political Science Review Vol.11(2), on pages $01-28$, is incorrect. Sergio Firpo and Renan Pieri are affiliated to Insper Instituto de Ensino e Pesquisa. The name and the institutional affiliation of the authors follow:

\section{Future electoral impacts of having a female mayor}

\author{
Paulo Arvate \\ Fundação Getúlio Vargas, Brazil \\ Sergio Firpo \\ Insper Instituto de Ensino e Pesquisa, Brazil \\ Renan Pieri \\ Insper Instituto de Ensino e Pesquisa, Brazil
}

http://dx.doi.org/10.1590/1981-3821201700030009 